\title{
Various content of manganese in selected forest tree species and plants in the undergrowth
}

\author{
E. Kula, P. Hrdlička, J. Hedbávný, P. Švec
}

Mendel Universityin Brno,Zemédélská 1, 61300 Czech Republic.E-mail:kula@mendelu.cz, hrdlicka@mendelu.cz,hedbavny@mendelu.cz,svec@mendelu.cz

Abstract: Kula, E., Hrdlička, P., Hedbávný, J., Švec, P. 2012: Differentiated content of manganese in selected forest trees and plants in the undergrowth. - Beskydy, 5 (1): 19-26

The content of manganese in foliage and other parts of trees and undergrowth plants were monitored in the site with heavy level of manganese in soil. The difference between the species and also between parts of the same plant was confirmed. Manganese was accumulated from the soil environment, especially by the species Betula pendula, Fagus sylvatica, Sorbus aucuparia, Larix decidua, Vaccinium myrtilus, Rubus ideus, Rubus fruticosus and Digitalis purpurea, where the content of manganese in leaves exceeded $5000 \mathrm{mg} \mathrm{kg}^{-1}$.

Keywords: manganese, Betula, Larix, Fagus, Quercus, Acer, Digitalis, Poa, Avenella, Calamagrostis, Ore Moutains

\section{Introduction}

Manganese is a micro-element necessary for normal growth and development of the plants. It changes its oxidation number in the range from 0 to + VII and is found in plants in the $\mathrm{Mn}^{2+}$, $\mathrm{Mn}^{3+}$ and $\mathrm{Mn}^{4+}$ form. Dominant form accessible to the plants are $\mathrm{Mn}^{2+}$ compounds. Manganese takes part mostly in redox reactions and as an activator of enzymes (Santadrea et al. 2000). In this area, photosynthesis enzymes are very important, as well as one antioxidant enzyme, superoxide dismutase (Grønflaten et al. 2005, Marschner 2006, Racek and Holeček 1999). The size of manganese ion is between magnesium and calcium ions. Thus, manganese can substitute these ions, but on the other hand, a competition for bonding places with these elements can also occur (Marschner 2006).

The plants can suffer both the lack and the surplus of Mn. Plants growing in soils with low content of $\mathrm{Mn}$ in the parent rock or in soils having $\mathrm{pH}>5.5$ suffer the lack of $\mathrm{Mn}$, especially if the carbonate content is higher (Marschner 2006, Mengel and Kirkby 2001). Chloroplasts are very sensitive to the lack of Mn, the biosynthesis of chlorophyll is greatly influenced. Unlike the lack of Mg, symptoms generally appear first in young leaves (Bergmann, 1988, Mengel and Kirkby 2001). The general critical value for the lack of $\mathrm{Mn}$ in leaves is in the range 10-20 mg $\mathrm{kg}^{-1}$ (Fernando et al. 2009, Marschner 2006) or 15-30 $\mathrm{mg} \mathrm{kg}^{-1}$ (Bergmann 1988). The surplus of $\mathrm{Mn}$ is found more often than the lack. The excessive intake and thus an increased content of manganese in plants occurs in soils with $\mathrm{pH}<$ 5.5 (Bergmann 1988). Unlike the lack of Mn, the critical value of the surplus at which the symptoms of toxicity are manifested varies in a wide range of values. The real content of Mn depends on plant species and the conditions of growth (Marschner 2006). Toxic surplus of manganese is manifested as brown spots at fully developed leaves (in fact, these spots are $\mathrm{MnO}_{2}$ precipitated in intercellular spaces), leaf chlorosis and necrosis in older leaves or the deformation of newly developing leaves and total growth limitation (Bergmann 1988, Horiguchi 1988, Kitao et al. 1997, Marschner 2006, Nable et al. 1988, Wissemeier and Horst 1987, Wissemeier and Horst 1992, Wu 1994). In the plants sensitive to the Mn content, the decrease of chlorophyll content up to $50 \%$ and corresponding growth limitation (Macfie and Taylor 1992) can be observed. The toxic effect of manganese can also cause 
a Ca-deficiency, leading to degradation and thus the lack of auxin (Horst 1988). Manganeseinduced deficiency can be found also for other elements, i.e. Ca, Mg or Fe (Kitao et al. 1997,Löhnis 1960).

The amount of manganese in soils is different according to various sources. The ranges of values $500-900 \mathrm{mg} \mathrm{kg}^{-1}, 50-500 \mathrm{mg} \mathrm{kg}^{-1}$ (Bergmann 1988), 300-1000 $\mathrm{mg} \mathrm{kg}^{-1}$ (Marschner 2006) or $200-3000 \mathrm{mg} \mathrm{kg}^{-1}$ (Mengel and Kirkby 2001) are given in literature. According to Liu et al. (2010) it is necessary to await the increase of $\mathrm{Mn}$ in soils due to the anthropogenic activities. The manganese form accessible to plants is $\mathrm{Mn}^{2+}$ or Mnin the form of complexes. The amount of accessible Mn is influenced by redox conditions and the presence of micro-organisms in the soil. Biologic oxidation to $\mathrm{Mn}^{\mathrm{IV}}$ compounds is quite common; these are insoluble in soil and unacceptable for the plants (Sigel and Sigel 1999). The amount of uptaken Mn depends on the soil conditions and on the plant species (Adriano 2001). Generally, higher content of $\mathrm{Mn}^{2+}$ ions can be expected in more acid soils (Mengel and Kirkby 2001), but here can occur even the intoxication, especially in the case of sensitive plants.

In soils with average content of manganese (i.e. up to $10000 \mathrm{mg} \mathrm{kg}^{-1}$ ) is the amount of manganese in plant dry matter mostly in the range of 50-800 $\mathrm{mg} \mathrm{kg}^{-1}$ (Fernando et al. 2009). However, values over $1000 \mathrm{mg} \mathrm{kg}^{-1}$ were also observed (Marschner 2006). Specific content depends on plant species and its organs. For example in assimilation organs of conifers the content of manganese can be up to $8000 \mathrm{mg} \mathrm{kg}^{-1}$ (Bergmann 1988). Generally the content of manganese in assimilation organs increases with the age which is in good accordance with low mobility of manganese. The sensitivity of plants to the surplus of manganese in tissues also varies (Marschner 2006). Some species are able to tolerate quite high amounts of $\mathrm{Mn}$; according to the literature the limits of tolerance can be up to $12000 \mathrm{mg} \mathrm{kg}^{-1}$ (Reeves 2006). At the manganese content > $1000 \mathrm{mg} \mathrm{kg}^{-1}$ the risk of phytotoxicity cannot be excluded. Specific manifestations further depend on the $\mathrm{pH}$ of soil and on the sustenance with other elements. The difference within the species must be also taken in account, for example Betula pendula Roth contained lesser amount of manganese in leaves than Betula pubescens Ehrh. (Koricheva and Haukioja 1995).

In the framework of the project "Betula“ implemented in the air polluted area of east Ore Mountains and Děčín Sandstone Highlands, large amount of manganese, excessing above mentioned values, was found in birch leaves. In the soils with high Mn content (up to
$3200 \mathrm{mg} \mathrm{kg}^{-1}$ ) some values of Mn content reached above the level of $10000 \mathrm{mg} \mathrm{kg}^{-1}$ (Hrdlička and Kula 1998, 2004, 2007). Even at these rather high concentrations the symptoms of Mn phytotoxicity were not observed in the analysed leaves. This is in a good accordance with the observation of Betula platyphylla var. japonica (Miq.) Hara seedlings (Kitao et al. 1997).

Plants having $>1000 \mathrm{mg} \mathrm{kg}^{-1}$ of $\mathrm{Mn}$ in their tissues without toxicity symptoms can be called the accumulators. However, there are also plants able to accumulate even higher amounts of metals. These are called "hyperaccumulators“. Such plants can be used to remove the metal contamination, mostly from soils, by the means of phytoremediation (Liu et al. 2010, Reeves and Baker 2000). Each element has a limit of its content in the plant, marked as a hyperaccumulation. For manganese, the common limit is at least $10000 \mathrm{mg} \mathrm{kg}^{-1}$ (Baker et al. 1994, Boyd 2004, Reeves and Baker 2000, Verbruggen et al. 2009). Manganese hyperaccumulators are for example Apocynaceae, Celastraceae, Clusiaceae, Myrtaceae and Proteacae (Proctor et al. 1989, Reeves and Baker 2000).

The aim of this paper is to define the differences in the maximum levels of manganese in the leaves, rhytidome and other parts of the selected trees, bushes and herbs growing in the same habitat conditions characterized by increased content of manganese in the soil.

\section{Site description}

Permanent research area, used for a continuous monitoring, is situated in eastern Ore Mountains, in the area Litvínov, altitude $488 \mathrm{~m}$ a.s.l., southwest exposition (approximately $50^{\circ} 38^{\prime} \mathrm{N}$; $13^{\circ} 37^{\prime} \mathrm{E}$ ). Parent rock is granite (Czech and Slovak geological map, 2012). The dynamic changes assessment of the elements content in the leaves of birch B.pendula showed that the amount of manganese in the site is above the lower limit values of the optimal/increased content classification group. Long-term values of the manganese content were high (1995: average $8790 \mathrm{mg} \mathrm{kg}^{-1}$, max. $9743 \mathrm{mg} \mathrm{kg}^{-1}$; 1998: 5230/6783 $\mathrm{mg} \mathrm{kg}^{-1}$; 2001: 7723/10212 $\mathrm{mg} \mathrm{kg}^{-1}$; 2004: 5946/8544 $\mathrm{mg} \mathrm{kg}^{-1}$; 2007: 11570/15730 $\mathrm{mg} \mathrm{kg}^{-1}$ ) (Hrdlička and Kula 1998, 2004, 2007). The investigation proved that enhanced content of manganese in birch leaves was a reaction to higher content of $\mathrm{Mn}$ in the soil (3250 $\mathrm{mg} \mathrm{kg}^{-1}$ - Hrdlička and Kula 2004).

The site was divided into three segments. The segments (marked Mn- 1 to $\mathrm{Mn}-3$ ) were different in kind of trees and herbaceous plants (see below). The content of manganese in the soil profile was: in fallen leaves (Mn-1/6603 $\mathrm{mg} \mathrm{kg}^{-1}$, 
Mn-2/4720 mg kg-1, Mn-3/8597mg kg-1; highest values); the level of manganese in Ah horizon was also differentiated (Mn-1/1216 $\mathrm{mg} \mathrm{kg}^{-1}, \mathrm{Mn}$ 2/770 $\mathrm{mg} \mathrm{kg}^{-1}, \mathrm{Mn}-3 / 2854 \mathrm{mg} \mathrm{kg}^{-1}$ ).

In the Mn-l part, the forest cover contains B. pendula (60\%), Sorbus aucuparia L. (20\%), Quercus robur L. (10\%) and Fagus sylvatica L. (10\%), with disseminated Prunus avium (L.) L. and Aesculus hippocastanum L. In the undergrowth there is mostly Digitalis purpurea (L.) (30\%), Calamagrostis epigeios (L.) Roth (20\%), Poa nemoralis L. (20\%) and Avenella flexuosa L. (10\%). In the Mn-2 part, B. pendula has 100\% representation with disseminated Q. robur L., S. aucuparia, Acer pseudoplatanus L. and new underplanting of Picea abies (L.) Karst., Pinus sylvestris L. and Tilia cordata Mill. Dominant plants in the undergrowth are C. epigeios (40\%), Rubus idaeus L. (20\%), Rubus fruticosus L. (10\%), A. flexuosa (20\%), P. nemoralis (10\%). In the part $\mathrm{Mn}-3$ the forest cover contains B. pendula (60\%), Larix decidua Mill. (20\%) and S. aucuparia (20\%), in the undergrowth is C. epigeios (40\%), R. fruticosus (20\%) and P. nemoralis (20\%). For the list of trees and herbaceous plants see Tab. 1 .

\section{Material and methods}

Samples were collected during the whole vegetation period (May $6^{\text {th }}-$ October $8^{\text {th }}$ 2010). In this paper, samples gathered on September $2^{\text {nd }} 2010$ are evaluated. Samples of 9 tree species and 14 plants of a herb layer: leaves and rhytidome from trees and bushes; roots, leaves, stems and flowers from herbs were taken and put individually into paper bags. After the open air pre-drying at laboratory conditions the samples were oven-dried at the temperature $70^{\circ} \mathrm{C}$. Rhytidome was removed from the branches with a ceramic knife. Clean samples were ground in the vibration mill (both containers and balls made of tungsten carbide) to the particle size $<0.5 \mathrm{~mm}$.

Sample mineralisation was performed by the means of microwave decomposition in MW ETHOS SEL (Microwave Solvent Extraction Labstation) with the mixture of $\mathrm{HNO}_{3}$ and ultra-pure water $1: 1 \mathrm{v} / \mathrm{v}(5 \mathrm{ml}+5 \mathrm{ml}$ ), sample weight was 0.1-0.5 g. After slow heating, mineralisation temperature was reached $\left(210^{\circ} \mathrm{C}\right)$ and kept for 20 min., ultra-pure water was added to the mineralised sample to total volume $25 \mathrm{ml}$. Quantitative determination of manganese was performed by the means of atomic absorption spectrometry (AAS) at the wave length $279.5 \mathrm{~nm}$ (Hedbávný,2010). The average values including standard deviations (for $\mathrm{n}=3$ ) were calculated from gathered data.

\section{Results}

Average measured values of the manganese content from September $2^{\text {nd }} 2010$ are given in the Table 1 together with max. values found during the vegetation period. Figure 1 shows average content of manganese in foliage and selected organs; values are sorted by manganese content in foliage.

Distinct differences were identified in the average manganese content among the trees before the end of the vegetation period (September $\left.2^{\text {nd }} 2010\right)$ in assimilation organs (1525$7852 \mathrm{mg} \mathrm{kg}^{-1}$ ) (Tab. 1). Highest average amount of manganese (>7000 $\mathrm{mg} \mathrm{kg}^{-1}$ ) was found in leaves of S. aucuparia and needles of $L$. decidua, while decreased level $\left(<3000 \mathrm{mg} \mathrm{kg}^{-1}\right)$ was characteristic for assimilation organs of $P$. abies (1-year-old needles), P. avium and A. hippocastanum. Values for remaining trees important for forestry ( $Q$. robur, B. pendula, F. sylvatica) oscillated around the level of $5000 \mathrm{mg} \mathrm{kg}^{-1}$ (Fig. 1). Peak values of the manganese content in trees were measured inconsistently during the vegetation period. The concentration of $\mathrm{Mn}$ in the larch needles was $12542 \mathrm{mg} \mathrm{kg}^{-1}$ (October $8^{\text {th }} 2010$ ) before needle fall, the maximum value in beech leaves was $10308 \mathrm{mg} \mathrm{kg}^{-1}$ (August $4^{\text {th }}$ 2010).

Although individual species in the herb undergrowth mostly have lower concentrations of manganese in leaves in comparison with trees, higher difference was found there (446$8040 \mathrm{mg} \mathrm{kg}^{-1}$ ). Assimilation organs (leaves) of $R$. ideaus and $R$. fructicosus show extreme average values over $7000 \mathrm{mg} \mathrm{kg}^{-1}$ (September $2^{\text {nd }} 2010$ ); maximum values for all these species reached almost $11000 \mathrm{mg} \mathrm{kg}^{-1}$ in the end of the vegetation period (Tab. 1, Fig. 1). Increased concentration of manganese was characteristic for another perennial plant, V. myrtillus (4922 $\mathrm{mg} \mathrm{kg}^{-1}$ ). On the other hand, grass species show relatively low level of manganese (1041-1250 $\mathrm{mg} \mathrm{kg}^{-1}$ ). Medicinal herb D. purpurea had increased concentration of manganese in leaves of two years old plants (2892 $\mathrm{mg} \mathrm{kg}^{-1}$ ) with peak value $8424 \mathrm{mg} \mathrm{kg}^{-1}$ (July $3^{\text {th }}$ 2010) (Tab. 1).

Rhytidome from branches of investigated trees and bushes collected at the same time as the samples of assimilation organs (September $2^{\text {nd }} 2010$ ) also demonstrated different amounts of manganese (1759-4962 $\mathrm{mg} \mathrm{kg}^{-1}$ ). Specific position has P. avium, because only in this tree the concentration of manganese found in rhytidome was higher than in leaves and peak amount samples $\left(8323 \mathrm{mg} \mathrm{kg}^{-1}\right.$ ) were collected on July $3^{\text {th }} 2010$ (Tab. 1). 
Tab. 1: Mean and maximal content of manganese in organs selected plants (site Litvínov, 2010).

\begin{tabular}{|c|c|c|c|c|c|}
\hline \multirow{2}{*}{$\begin{array}{ll} & \text { Plants } \\
\text { Oak } & \end{array}$} & \multirow{2}{*}{$\begin{array}{c}\text { Organs } \\
\text { leaf }\end{array}$} & \multirow{2}{*}{$\begin{array}{c}\begin{array}{c}\text { Mean } \pm \text { stand. dev.* } \\
\left(\mathbf{m g ~ k g}^{-1}\right)\end{array} \\
5368 \pm 121\end{array}$} & \multicolumn{2}{|c|}{$\begin{array}{l}\text { Maximum** } \\
\text { date }\left(\mathrm{mg} \mathrm{kg}^{-1}\right)\end{array}$} & \multirow{2}{*}{$\begin{array}{c}\begin{array}{c}\text { Limit value } \\
\left(\mathbf{m g ~ k g} \mathbf{~ k g}^{-1}\right)\end{array} \\
60-2500(\mathrm{~F})\end{array}$} \\
\hline & & & 3.7. & 6337 & \\
\hline Quercus robur $\mathrm{L}$. & rhytidome & $3785 \pm 815$ & 4.8. & 5651 & \\
\hline Birch & leaf & $5125 \pm 481$ & 8.10. & 8244 & $30-100(B)$ \\
\hline Betula pendula Roth & rhytidome & $1759 \pm 254$ & 8.10. & 2541 & \\
\hline Beech & leaf & $5488 \pm 2356$ & 4.8. & 10309 & $60-2500(F)$ \\
\hline Fagus sylvatica $\mathrm{L}$. & rhytidome & $1931 \pm 615$ & 8.10. & 2541 & \\
\hline Maple & leaf & $3124 \pm 226$ & 8.10. & 6323 & $30-100(B)$ \\
\hline Acer pseudoplatanus $\mathrm{L}$. & rhytidome & $3952 \pm 1315$ & 8.10. & 6173 & \\
\hline Rowan & leaf & $7852 \pm 265$ & 2.9. & 8183 & \\
\hline Sorbus aucuparia L. & rhytidome & $2032 \pm 508$ & 4.8. & 3511 & \\
\hline Horse chestnut & leaf & $2714 \pm 279$ & 8.10. & 4314 & \\
\hline Aesculus hippocastanum $\mathrm{L}$. & rhytidome & $1775 \pm 634$ & 2.6. & 3774 & \\
\hline Cherry & leaf*** & 1525 & 8.10. & 2125 & $30-100(B)$ \\
\hline Prunus avium (L.) L. & rhytidome*** & 4962 & 3.7. & 8323 & \\
\hline Larch (Larix decidua Mill.) & needle & $7012 \pm 1337$ & 8.10. & 12542 & $35-200(B)$ \\
\hline Norway spruce (Picea abies (L.) Karst.) & needle & $2144 \pm 111$ & 8.10. & 2945 & $20-2000(F)$ \\
\hline Raspberry & leaf & $7165 \pm 1755$ & 8.10. & 10953 & $30-100(B)$ \\
\hline Rubus idaeus L. & stem & $2114 \pm 530$ & 2.6. & 6967 & \\
\hline Blackberry & leaf & $8040 \pm 2585$ & 2.9. & 10928 & $30-100(B)$ \\
\hline Rubus fruticosus $\mathrm{L}$. & stem & $1987 \pm 125$ & 2.6. & 4471 & \\
\hline Blueberry & leaf & $4921 \pm 1487$ & 2.9. & 7022 & \\
\hline Vaccinium myrtillus $\mathbf{L}$. & twigs & $2745 \pm 653$ & 3.7. & 3767 & \\
\hline Elderberry (Sambucus nigra L.) & leaf & $985 \pm 58$ & 2.6. & 1303 & \\
\hline Wavy hair-grass (Avenella flexuosa L.) & leaf & $1041 \pm 221$ & 3.7. & 1874 & \\
\hline Sticky groundsel (Senecio viscosus $\mathrm{L}$.) & leaves and stem & $955 \pm 237$ & 8.10. & 2894 & \\
\hline Foxglove & leaf & $2892 \pm 1118$ & 3.7. & 8424 & \\
\hline Digitalis purpurea $(\mathrm{L})$. & root & $2149 \pm 476$ & 4.8. & 4257 & \\
\hline Bluegrass & leaf & $1250 \pm 305$ & 8.10. & 2392 & $35-100(\mathrm{~B})$ \\
\hline Poa pratensis $\mathbf{L}$. & bloom & $1623 \pm 55$ & 8.10. & 2576 & \\
\hline Sorrel & leaf & $446 \pm 75$ & 4.8. & 5626 & \\
\hline Rumex acetosa $\mathrm{L}$. & bloom & $328 \pm 65$ & 4.8. & 1007 & \\
\hline Wood small-reed & leaf & $1093 \pm 415$ & 6.5 . & 1765 & \\
\hline Calamagrostis epigejos (L.) & bloom & $662 \pm 56$ & 3.7. & 1226 & \\
\hline Nightshade & leaf & $1585 \pm 246$ & 8.10. & 2514 & \\
\hline Atropa bella-donna $\mathrm{L}$. & stem & $664 \pm 69$ & 2.9. & 764 & \\
\hline $\begin{array}{l}\text { Male fern (Dryopteris filix-mas (L.) } \\
\text { Schott }\end{array}$ & leaf & $1306 \pm 80$ & 8.10. & 2442 & \\
\hline $\begin{array}{l}\text { Downy hemp-nettle } \\
\text { (Galeopsis speciosa Mill.) }\end{array}$ & leaves and stem & $3371 \pm 988$ & 3.7. & 4715 & \\
\hline Hypericum (Hypericum perforatum L.) & leaves and stem & $1273 \pm 364$ & 8.10. & 2234 & \\
\hline
\end{tabular}

\# References: (F) - Fürst (2005); (B) - Bergmann (1988)

* sampling on 2.9.2010

** date of sampling (2010) related to maximum

*** only one sample, others three samples 


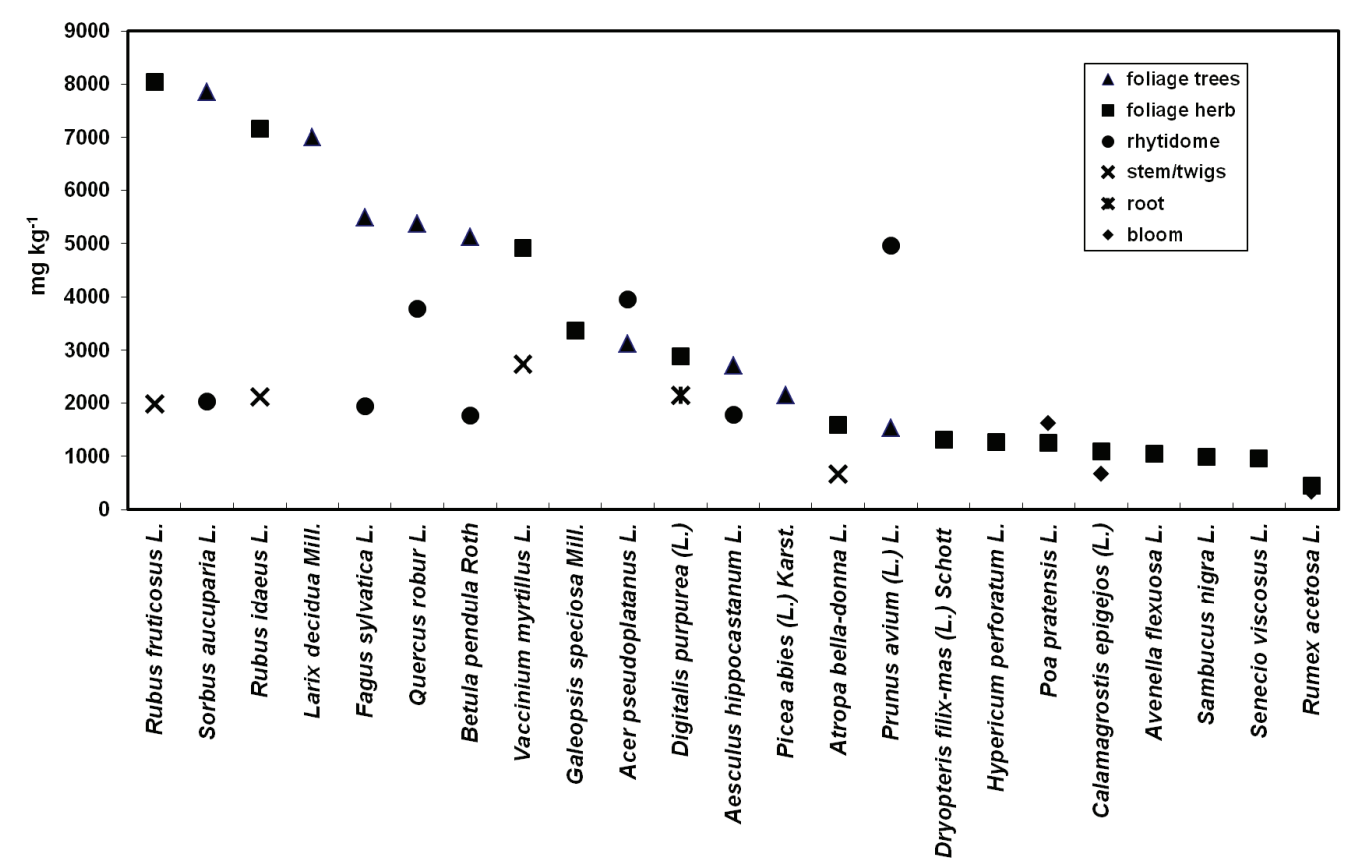

Fig. 1: Average content of manganese in foliage and organ selected plants (sorted by content of manganese in foliage).

\section{Discussion}

The content of manganese in monitored area was differentiated i) among individual parts of the same plant (leaves vs. rhytidome, leaves vs. roots etc.), ii) among the same parts of different plants. Highest inter-species differences in the manganese content described Reimann et al. (2007) between Dryopteris filix-mas (L.) Schott. $\left(239 \mathrm{mg} \mathrm{kg}^{-1}\right)$ and birch leaves $\left(2138 \mathrm{mg} \mathrm{kg}^{-1}\right)$. We can confirm (Fig. 1) this by our investigation (birch average $5125 \mathrm{mg} \mathrm{kg}^{-1}$, max. $8243 \mathrm{mg} \mathrm{kg}^{-1}$ and D. filix-mas average 1306 max. $2442 \mathrm{mg} \mathrm{kg}^{-1}$ ). The content of manganese increased during the vegetation period, it corresponded with generally very low mobility of manganese (Langheinrich et al. 1992, Marschner 2006). Optimal concentrations of manganese or even phytotoxicity level for some plants given in literature and in IUFRO sources (Bergmann 1988, Fürst 2005) was exceeded several times in the investigated species, while neither necrotic phenomenons nor perishing of plant was observed during the year 2010 .

The sensitivity of plants to the surplus of Mn is different. As for the trees, S. aucuparia, L. decidua, F. sylvatica, Q. robur, B. pendula are very tolerant, as for herbaceous plants, are very tolerant $R$. fruticosus, R. idaeus, V. myrtillus (in all leaves samples content of manganese $>5000 \mathrm{mg} \mathrm{kg}^{-1}$, Fig. 1).
Soil environment (horizon, humidity, nutrient content, etc.) is a limiting factor for the manganese content in leaves. In various trees, a difference of manganese content in leaves was found (Heilmeier et al. 2000) according to the basalt (the amount of Mn in soil $1284 \mathrm{mg} \mathrm{kg}^{-1}$ ) and rhyolite bedrock ( $325 \mathrm{mg} \mathrm{kg}^{-1}$ ), specifically for F. sylvatica (3600-4600/700-1000 $\mathrm{mg} \mathrm{kg}^{-1}$ ), S. aucuparia (2600-3100/2100-3200 mg kg-1) and P. abies (2700-2900/900-2100 $\left.\mathrm{mg} \mathrm{kg}^{-1}\right)$. Our results indicate comparable amount of $\mathrm{Mn}$ in the assimilation organs of P. abies (2781 $\mathrm{mg} \mathrm{kg}^{-1}$ ), the values for F. sylvatica and aucuparia were significantly higher (Tab. 1). In the case of L. decidua needles the content of $\mathrm{Mn}$ found during our research (max. $12542 \mathrm{mg} \mathrm{kg}^{-1}$ ) shows high rate of accumulation (due to the content of Mn in soil - $3250 \mathrm{mg} \mathrm{kg}^{-1}$ - Hrdlička and Kula 2004) in comparison with the values $911-1400 \mathrm{mg} \mathrm{kg}^{-1}$ for plants growing on the soil with low manganese content (Skřivan et al. 2002). Similar conclusions can be deduced for F. sylvatica - Litvínov max. $10309 \mathrm{mg} \mathrm{kg}^{-1}$ (Tab. 1) vs. $372-953 \mathrm{mg} \mathrm{kg}^{-1}$ (Machava and Barna 2005).

Higher amount of manganese can be found in tissues of $V$. myrtillus. In plants growing on soil substrate with manganese content $300-400 \mathrm{mg} \mathrm{kg}^{-1}$ were found values 888-1941 mg kg-1 in leaves (Gupton and Spiers 1992), in plants growing on soil substrate with 
manganese content $80 \mathrm{mg} \mathrm{kg}^{-1}$ was in leaves found $550 \mathrm{mg} \mathrm{kg}^{-1}$, in stems was $1016 \mathrm{mg} \mathrm{kg}^{-1}$ (Grønflaten et al. 2005). In the low immision area in Poland was found 1044-2120 mg kg-1 of Mn in

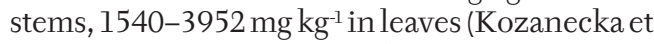
al. 2002). In the catchment of Lesní Potok (Czech Republic), where the total content of manganese in the soil was $<818 \mathrm{mg} \mathrm{kg}^{-1}$, the content of $\mathrm{Mn}$ in F. sylvatica leaves was $1206 \mathrm{mg} \mathrm{kg}^{-1}$ and in P. abies needles it was $715 \mathrm{mg} \mathrm{kg}^{-1}$ (Navrátil et al. 2007). Our values (see Tab. 1) were higher, which is in good accordance with the amount of $\mathrm{Mn}$ in the soil (see Hrdlička and Kula 2004). Most species from the Ericaceae family are the accumulators of manganese, without any signs of toxicity in leaves up to $15000 \mathrm{mg} \mathrm{kg}^{-1}$ (Korcak 1989). Another part of the undergrowth with high amount of manganese in leaves was R. idaeus (Kowalenko 2005, Sikiric et al. 2009, Wislocka et al., 2006). The content of manganese varied in the range 182-949 $\mathrm{mg} \mathrm{kg}^{-1}$ (Wislocka et al. 2006), but also just in the range $280-360 \mathrm{mg} \mathrm{kg}^{-1}$ (Kowalenko 2005). Measured values of manganese content, $7165 \mathrm{mg} \mathrm{kg}^{-1}$ with maximum $10952 \mathrm{mg} \mathrm{kg}^{-1}$ without any signs of phytotoxicity, show high toleration to manganese. R. fruticosus comes from the same genus and also shows ability to tolerate high level of manganese (Tab. 1).

\section{References}

Adriano, D. C. 2001: Trace elements in the terrestrial environment: biogeochemistry, bioavailability, and risk of metal. Second ed., New York, Berlin, Heidelberg: Springer Verlag, 867 pp.

Baker, A. J. M., Reeves, R. D., Hajar, A. S. M. 1994: Heavy metal accumulation and tolerance in British populations of the metallophyte Thlaspi caerulescens J. \& Presl (Brassicaceae). New Phytologist, 127: 61-68.

BERGMANN, W. 1988: Ernährungsstörungen bei Kulturpflanzen. (Entstehung, visuelle und analytische Diagnose). Second ed., Jena: VEB Gustav Fischer Verlag, $762 \mathrm{~S}$.

BoyD, R. S. 2004: Ecology of metal hyperaccumulation. New Phytologist, 162: 563-567.

Czech and SlovaK Geological Map: $h t t p: / / w w w$. geology.cz/app/ciselniky/lokalizace/show_map.ph p? mapa $=$ g50zj $\sigma y=790890 \sigma x=976352 \sigma s=1$ (accessed 30.5.2012)

Fernando, D. R., Guymer, G., Reeves, R. D., Woodrow, I. E., BAKer, A. J. M., Batianoff, G. N. 2009: Foliar Mn accumulation in eastern Australian herbarium specimens: prospecting for ‘new' Mn hyperaccumulators and po-

\section{Conclusion}

The difference among both various trees and undergrowth plant species and different tissues of the same plant growing in the same location conditions was verified.

According to the rate of accumulation and prevalence, B. pendula, F. sylvatica, S. aucuparia, L. decidua, V. myrtilus, R. ideus, R. fruticosus and D. purpurea can be classified as suitable plant species to use for the surface definition of the manganese contamination in the environment, with the realisation during the season with expected maximum content.

\section{Acknowledgement}

This paper was carried out under projects funded by the grant project VZ MSM 6215648902 , and on the financial support of regional join stock companies and concerns: $\mathrm{Ne}-$ tex Ltd. in Děčín, Constellium Děčín Extrusions Ltd. in Děčín, Chart Ferox Co in Děčín, District Authorities in Děčín, Nadace ČEZ Co. Prague, Lafarge cement Co. in Čížkovice, Severočeské doly Co. Chomutov, Dieter Bussmann Ltd. in Ústín. L.

tential applications in taxonomy. Annals of Botany, 103: 931-939.

FÜRST, A. 2005: Classification Values for European Foliar Data http://bfw.ac.at/rz/bfwcms. web?dok=2888 (accessed 6.42012)

Grønflaten, L. K., Amundsen, L., Frank, J., SteinNes, E. 2005: Influence of liming and vitality fertilization on trace element concentrations in Scots pine forest soil and plants. Forest Ecology and Management, 213: 261-272.

Gupton, G. L., Spiers, J. M. 1992: Inheritance of Tolerance to Mineral Element-induced Chlorosis in Rabbiteye Blueberry. Hort Science, 27: 148-151.

HedBĀ́nný, J. 2010: Element determination by AAS method. Analytical methods, Mendel Univerzity in Brno, 20 pp.

Heilmeier, H., Baronius, K., Kuhn, A. J., Opfermann, M., Nebe, W. 2000: Wachstum und Ernährung von Eberesche, Buche und Fichte im Gefässversuch mit immissionbelasteten Bodensubstraten aus dem Erzgebirge. Journal of Plant Nutrition and Soil Science, 163:57-63.

HoriguchI, T. 1988: Mechanism of manganese toxicity and tolerance of plants. Soil Science and Plant Nutrition, 34: 65-73. 
Horst, W. J. 1988: The physiology of manganese toxicity. In: Graham, R. D., Hannam, R. J., Uren, N. C. (eds.): Manganese in Soils and Plants, Dordrecht, The Netherlands: Kluwer Academic, 175-188.

HrdLIČKA, P., KulA, E. 1998: Element content in leaves of birch (Betula verrucosa Ehrh.) in an air polluted area. Trees - Structure Function, 13: 68-73.

HrdličKa, P., Kula, E. 2004: Changes in the chemical content of birch (Betula pendula Roth) leaves in the air polluted Krusne hory mountains. Trees - Structure Function, 18: 237-244.

HrdličKa, P., KulA, E. 2007: Obsah prvkü $v$ asimilačních orgánech brízy Betula pendula Roth a jejich dynamika (1995-2007). Výzkumná zpráva, Brno: LDF MZLU, [Content of elements in assimilation organs of birch Betula pendula Roth and its dynamics (1995-2007). Research report, Brno: LDF MZLU], 32 pp.

Kitao, M., Lei, T. L., KoiKe, T. 1997: Effects of manganese toxicity on photosynthesis of white birch (Betula platyphylla var. japonica) seedlings. Physiologia Plantarum, 101: 249-256.

KoRCAK, R. 1989: Variation in nutrient requirements of Blueberries and other Calcifuges. Hort Science, 24: 573-578.

Koricheva, J., Haukioja, E. 1995: Variations in chemical composition of birch foliage under air pollution stress and their consequences for Eriocrania miners. Environmental Pollution, 88: 41-50.

Kowalenko, C. G. 2005: Accumulation and distribution of micronutrients in Willamette red raspberry plants. Canadian Journal of Plant Science, 85: 179-191.

Kozanecka, T., Chojnicki, J., Kwasowski, W. 2002: Content of heavy metals in plant from pollution-free regions. Polish Journal of Environmental Studies, 11: 395-399.

Langheinrich, U., Tischner, R., Gobold, D. L. 1992: Influence of a high Mn supply on Norway spruce (Picea abies [L.] Karst.) seedlings in relation to nitrogen source. Tree Physiology, 10: 259-271.

Liu, P., TAng, X., Gong, C., Xu, G. 2010: Manganese tolerance and accumulation in six $\mathrm{Mn}$ hyperaccumulators or accumulators. Plant and Soil, 335: 385-395.

LöHNIs, M. P. 1960: Effect of magnesium and calcium supply on the uptake of manganese by various crop plants. Plant and Soil, 12: 339-376.

Macfie, S. M., TAYlor, G. J. 1992: The effects of excess manganese on photosynthetic rate and concentration of chlorophyll in Triticum aestivum grown in solution culture. Physiologia Plantarum, 85: 467-475.

Machava, J., Barna, M. 2005: The influence of stand density on Mn and Fe concentration in Beech leaves. Journal of Forest Science, 5l: 225-236.

Marschner, H. 2006: Mineral Nutrition of Higher Plants. Second ed., Amsterdam: Academic Press, 890 pp.

Mengel, K., KIRKBy, E. A. 2001: Principles of Plant Nutrition. Fifth ed., Dordrecht, The Netherlands: Kluwer Academic Publishers, 849 pp.

Nable, R. O., Houtz, R. L., Cheniae, G. M. 1988: Early inhibition of photosynthesis during development of Mn toxicity in tobacco. Plant Physiology, 86: 1136-1142.

Navrátil, T., Shanley, J. B., SkŘivan, P., Krám, P., Minaljevič, M., Drahota, P. 2007: Manganese biogeochemistry in a central Czech Republic catchment. Water, Air, and Soil Pollution, 186: 149-165.

Proctor, J., Phillips, C., Duff, G. K., Heaney, A., Robertson, F. M. 1989: Ecological studies on gunung silam, a small ultrabasic mountain in sabah, malaysia. Journal of Ecology, 77: 317-331.

RACEK, J., HolečEK, V. 1999: Enzymy a volné radikály. [Enzymes and free radicals] Chemické listy, 93: 774-780.

ReEves, R. D. 2006: Hyperaccumulation of trace elements by plants. In: Morel, J. L., echevarria, G., Goncharova, N. (eds.): Phytoremediation of metal-contaminated soils, Berlin: Springer, 25-52.

Reeves, R. D., BAKer, A. J. M. 2000: Metal - accumulating plants. In: RASKIN, I., ENSLEY, B. D. (eds.): Phytoremediation of toxic metals: using plants to clean-up the environment, New York: John Wiley and Sons, 193-230.

Reimann, C., Arnolddussen, A., Finne, T. E., Koller, F., Nordgulen, Ø., Englmaier, P. 2007 : Element contents in mountain birch leaves, bark, and wood under different anthropogenic and geogenic conditions. Applied Geochemistry, 22: 1549-1566.

Santadrea, G., Pandolfi, T., Bennici, A. 2000: A physiological characterization of $\mathrm{Mn}$ tolerant tobacco plants selected by in vitro culture. Plant Science, 150: 163-170.

Sigel, A., Sigel, H. 1999: Metal ions in biological systems. Manganese and its role in biological processes. Basel, Switzerland: Institute of Inorganic Chemistry, University of Basel, 761 pp. Sikiric, B., Mrvic, V., Stevanovic, D., MaKsimovic, S., Stajkovic, O., Bogdanovic, D. 2009: The effects of calcification, urea and Al salts 
on $\mathrm{Fe}, \mathrm{Mn}$ and $\mathrm{Al}$ contents in the soil and raspberry leaves. Agrochimica, 53: 250-259.

Skřitvan, P., Navrátil, T., Sequens, J., Kurian, M., Kvidová, O. 2002: Biogeochemical cycles of metals in the environment: Factors controlling their content in the tissues of selected forest tree species. Scientia Agriculturae Bohemica, 33: 71-78.

UN-ECE 2010: Manual on methods and criteria for harmonized sampling, assessment, monitoring and analysis of the effects of air pollution on forests. Hamburg, Germany: 19 pp.

Verbruggen, N., Hermans, C., Schat, H. 2009: Molecular mechanisms of metal hyperaccumulation in plants. New Phytologist, 181: 759-776.

Wislocka, M., KrawczyK, J., KlinK, A., MorRISON, L. 2006: Bioaccumulation of Heavy
Metals by Selected Plant Species from Uranium Mining Dumps in the Sudety Wts., Poland. Polish Journal of Environmental Studies, 15: 811-818.

Wissemeier, A. H., Horst, W. J. 1987: Callose deposition in leaves of cowpea (Vigna unguiculata [L.] Walp.) as a sensitive response to high manganese supply. Plant and Soil, 102: 283-286.

Wissemeier, A. H., Horst, W. J. 1992: Effect of light intensity on manganese toxicity symptoms and callose formation in cowpea (Vigna unguiculata [L.] Walp.). Plant and Soil, 143: 299-309.

Wu, S. 1994: Effect of manganese excess on the soybean plant cultivated under various growth conditions. Journal of Plant Nutrition, 17: 993-1003. 